Folia Historica Cracoviensia, 22: 2016, s. 641-645

DOI: http://dx.doi.org/10.15633/fhc.2100

Włodzimierz Siedlik

Uniwersytet Papieski Jana PawŁa iI w Krakowie

\title{
Repertuar zespołów chóralnych - z perspektywy dyrygenta
}

„Chóralistyka to artyzm i sztuka pokory. To zbiorowe kształtowanie dzieła artystycznego podporządkowane wizji i woli dyrygenta. Próba chóru to lekcja rozumnej spolegliwości i szacunku dla zaangażowania zbiorowości ludzkiej w dźwiękowe ucieleśnienie dzieła. Chóralistyka to wieloosobowy akt zawierzeniu pięknu muzyki, wyznawany z ogromną determinacją". Te piękne słowa napisał rektor Akademii Muzycznej im. Feliksa Nowowiejskiego w Bydgoszczy prof. zw. Jerzy Kaszuba w słowie wstępnym w publikacji Chóralistyka polska w kontekście 3o-lecia Podyplomowych Studiów Chórmistrzowskich.

Tradycje śpiewu chóralnego sięgają dawnych wieków. Są zakorzenione w społeczeństwie bardzo głęboko. Ze źródeł ikonograficznych i kancjonałów możemy się dowiedzieć, że średniowiecze to epoka, w której zaczyna się rozwijać chóralistyka. Przyporządkowana do celów liturgicznych, wykonywana była głównie w klasztorach przez głosy męskie. Dopiero w renesansie chór osiąga znakomite brzmienie poprzez dodanie do głosów męskich brzmienia głosów chóru chłopięcego. Oprócz chłopców przed mutacją z pięknym krystalicznym głosem w chórze śpiewali kastraci. Choć Kościół był przeciwny okaleczeniom ciała męskiego, to najczęstszym kontrahentem zamawiającym kastratów była papieska Cappella Sistina. W renesansie ukształtował się typowy układ chóralny sАтв. W baroku oprócz przestrzeni religijnej chóralistyka wkroczyła w obszar muzyki świeckiej. Chóry z wielkim powodzeniem zaistniały w operach włoskich. Ogromny rozwój chóralistyki, a także repertuaru $\mathrm{z}$ nim związanego widzimy w oratoriach, w których muzyka chóralna uzyskała wiodącą rolę. Niektóre oratoria były wykonywane w ogromnych obsadach, np. w roku 1791 oratorium Mesjasz G. F. Haendla wykonane zostało w obsadzie 1000 artystów. Muzyka klasyczna wyznaczyła chórom wielkie wymagania wokalne, w których głos ludzki musi sprostać bardzo wysublimowanym oczekiwaniom cenionych i wybitnych kompozytorów. A co się dzieje w Polsce? Już w xv wieku ukazują się dzieła Mikołaja z Radomia świadczące o wysokiej kulturze tego okresu. Polska chóralistyka rozkwita 
dzięki powstaniu Kapeli Rorantystów na Wawelu (1540). Do czasów rozbiorów powstają chóry kościelne i dworskie, które z braku podstaw utrzymania wraz z upadkiem Rzeczypospolitej znikną z życia muzycznego. Inaczej sytuacja przedstawia się w Galicji, gdzie dzięki ogromnej determinacji osób świeckich powstało kilka znanych towarzystw śpiewaczych, np. Krakowie w 1817 roku. Dużą rolę odegrały także ośrodki uniwersyteckie. W Krakowie powstał Krakowski Chór Akademicki, w Warszawie słynna „Harfa” prowadzona przez legendarnego dyrygenta Wacława Lachmana. Dzięki ogromnej muzycznej aktywności chórów akademickich prawie we wszystkich większych ośrodkach zaczęly powstawać nowe zespoły chóralne, które były prowadzone przez bardzo dobrych muzyków i oddanych amatorów. Podczas zaborów polskie zespoły podtrzymywały ducha narodu. Polska pieśń chóralna uczyła języka polskiego, krzepiła serca, uczyła także historii i zarazem dumy narodowej i heroizmu. Chóry zrzeszały się w potężne organizacje, które przeciwstawiały się zaborcom niszczącym kulturę i byt narodu. Jak słusznie zauważa dr Jakub Puchalski, „Rewolucja Francuska przyniosła nie tylko ścięcie króla oraz deklarację praw człowieka i obywatela, ale także muzykę rewolucyjną, w której masowa pieśń chóralna odgrywała dużą rolę. $\mathrm{Na}$ różnych wiecach, uroczystościach ludowych, patriotycznych wykonywano pieśni chóralne w obsadzie kilku tysięcy osób. W ten sposób zaczęły powstawać towarzystwa śpiewacze we Francji, w Niemczech - słynna Sing-Akademie w Berlinie czy rozsiane szczególnie na terenie Wielkopolski Towarzystwa Św. Cecylii”'. W Polsce powstają profesjonalne zespoły chóralne, które działają w strukturach organizacyjnych liczących się filharmonii, a także publicznego nadawcy, jakim było i jest Polskie Radio.

Analizując programy koncertowe zespołów chóralnych z różnorakich kreacji artystycznych - koncertów, konkursów oraz festiwali, możemy uzyskać odpowiedź na pytanie dotyczące kryteriów doboru repertuaru przez dyrygentów.

Tym razem ograniczę się do festiwali organizowanych w Polsce po II wojnie światowej oraz do twórczości polskich kompozytorów. Do najbardziej prestiżowych konkursów należy Ogólnopolski Turniej Chórów „Legnica Cantat”. Tradycje tego turnieju nawiązują do bogatej przeszłości muzycznej Legnicy, do jej historii utrwalonej w zabytkach architektury sakralnej i świeckiej. Budowniczy zamku legnickiego Henryk Brodaty był trubadurem. Od czasu powstania grodu aż do końca XVI wieku istniała w Legnicy kapela zamkowa. Z Legnicy pochodzi wybitny kompozytor Jerzy Liban, którego możemy zaliczyć do wybitnych twórców

1 J. Puchalski, Od kultu do radości śpiewania, „Scala. Edukacyjny Magazyn Muzyczny” 2015 nr 5, s. 5 . 
polskiej kultury epoki odrodzenia. Głównym inicjatorem i długoletnim organizatorem turnieju „Legnica Cantat” był Henryk Karliński - niestrudzony działacz społeczny i dyrygent chóru „Madrygał”. Pierwszy turniej odbył się w 1967 roku i zgromadził 12 zespołów. Zwycięzcą pierwszego turnieju, który zdobył Brązową Lutnię im. Jerzego Libana z Legnicy, był Chór Uniwersytetu Wrocławskiego pod dyrekcją Mieczysława Matuszczaka. Zapoczątkował on zwycięską passę zespołów studenckich w kolejnych edycjach festiwalu. Najczęściej wykonywanym utworem podczas turnieju był Już się zmierzcha Wacława z Szamotuł, a także Oczy me miłe anonimowego autora. Kolejnym utworem bijącym rekordy popularności był Aleć nade mna Wenus Mikołaja z Krakowa. Wśród 77 kompozycji Józefa Świdra najczęściej wykonywane były: Cantus gloriosus, Marsz, Moja piosnka. Pośród 36 kompozycji Andrzeja Koszewskiego Zdrowaś, Królewno Wyborna została wykonana 20-krotnie, a Kotek 16-krotnie. Spośród 32 psalmów Mikołaja Gomółki 17-krotnie został wykonany psalm Nieście chwałę mocarze, 18-krotnie Kleszczmy rękoma, 12-krotnie Siedzac po niskich brzegach, Wacława z Szamotuł Ego sum pastor bonus 15-krotnie, Mikołaja Zieleńskiego Viderunt omnes fines terrae 22-krotnie, Grzegorza Gerwazego Gorczyckiego Tota pulchna es Maria 11-krotnie, Stanisława Wiechowicza $Z$ tamtej strony rzeki 18-krotnie, Romualda Twardowskiego Preludio e toccata 14-krotnie. Podczas turnieju pojawiły się utwory, które zostały wykonane tylko jeden raz, są to m.in. Bolesława Walka-Walewskiego Kołysanka rosyjska, Alfreda Gradsteina Cześć partii oraz $\mathrm{Na}$ prawo most, na lewo most, Benedykta Konowalskiego Lenin $w$ Poroninie Jacka Różyckiego Kołysanka ludowa. Zapewne zauważycie państwo, że w repertuarze chórów największą liczbę pozycji stanowią utwory sakralne, opracowania utworów ludowych, utwory o różnorodnej tematyce. Pojawiają się także utwory socrealizmu. Ulubionym motywem niektórych kompozytorów był wówczas traktor i jego kierowca. Do znanych i śpiewanych jednogłosowo pieśni zaliczyć możemy Traktorzystkę Witolda Friemana, Traktor Marii Kaczurbiny czy Janka Traktorzystę Witolda Rudzińskiego. Na cześć pracy powstała duża liczba kantat (Tadeusz Machl - Dzień pracy). W swoich utworach kompozytorzy wspominają rewolucję październikową. Tadeusz Barid oprócz Pieśni o rewolucji komponuje Balladę o żotnierskim kubku. Kazimierz Serocki komponuje utwór o przymiotach Murarza warszawskiego. W swoim Lenino Jerzy Gert wspomina II wojnę światową. W Polsce realizm socjalistyczny w postaci doktrynalnej istniał w latach 1949-1956. I edycja turnieju w Legnicy odbyła się w 1967 roku, a więc 11 lat po zamknięciu ideowego narzędzia partii komunistycznej. Nasuwa się więc pytanie, jakimi pobudkami kierowali się dyrygenci przy doborze repertuaru dla swoich chórów. To pytanie pozostawiam bez odpowiedzi. 
W ostatnich latach można zauważyć spadek zainteresowania muzyką dawną na korzyść muzyki współczesnej o bardzo wysokim stopniu trudności, co zapewne wiąże się z ogromnymi możliwościami i umiejętnościami wykonawczymi obecnych zespołów chóralnych. W repertuarze obecnej „Legnicy Cantant” króluje - szczególnie w repertuarze chórów akademickich - rozległy, bardzo ambitny program, którego nie powstydziłyby się profesjonalne zespoły chóralne. Trzeba stwierdzić, że w naszym kraju od wielu już lat chóry akademickie - ostatnio także z akademii muzycznych - wyznaczają poziom wykonawstwa chóralnego. To dzięki tym zespołom twórczość polskich kompozytorów prezentowana jest na prestiżowych konkursach, festiwalach, koncertach nie tylko w Polsce, ale także w liczących się na świecie kreacjach artystycznych. Chóry akademickie są także organizatorami wielu konkursów i festiwali, podczas których wykonywane są prawykonania nowych dzieł chóralnych.

Przykładowo w Poznaniu od 1998 roku odbywa się festiwal „Universitas Cantat”. Inicjatorem tego wydarzenia był prof. Stefan Jurga, ówczesny rektor Uniwersytetu im. Adama Mickiewicza w Poznaniu, wieloletni członek zespołu chóralnego, a następnie prezes Chóru Akademickiego UAM. Dyrektorem artystycznym festiwalu jest od samego początku Krzysztof Szydzisz, profesor Akademii Muzycznej w Bydgoszczy, a wicedyrektorem - Joanna Piech-Sławecka. Oboje są dyrygentami Chóru Kameralnego UAM. Dotychczas zostały wykonane następujące utwory finałowe: 1998 - Litania ad Spiritum Sanctum (Litania do Ducha Świętego) Zbigniewa Kozuba,

1999 - Angelus Wojciecha Kilara, tekst: modlitwa Pozdrowienie Anielskie, 2000 - Beati estis Zbigniewa Kozuba, 2001 - Ad Iuventatem Marka Jasińskiego, tekst: Oda do młodości Adama Mickiewicza w łacińskiej parafrazie Andrzeja Wójcika,

2002 - Symfonia Nihil homine Mirabilius Krzesimira Dębskiego, tekst: Antygona Sofoklesa,

2003 - II Symfonia Ver Redit (Powrót wiosny) Krzesimira Dębskiego, tekst: Die Gedichte des Codex Buranus, Zürich und München 1974, nr 74, 2005 - Symfonia Festinemus amare homines Pawła Łukaszewskiego, 2007 - Raptus Europae (Porwanie Europy) Marka Jasińskiego, tekst: fragmenty starogreckiego tekstu Europa Moschosa w przekładzie łacińskim Karla Friedricha Ameisa, 2009 - Exegi Monumentum Romualda Twardowskiego, 2011 - Amor Vincit Miłosza Bembinowa, tekst: fragmenty Carmina Burana, 2013 - Origo Mundi Jacka Sykulskiego, tekst: fragmenty Metamorfoz Owidiusza, 2015 - Arion Zuzanny Koziej, tekst: fragmenty Kalendarza (Fasti) Owidiusza. 
Kolejną znakomitą przestrzenią wykonawczą dla chórów i dyrygentów jest Ogólnopolski Konkurs Dyrygentów Chóralnych im. prof. Stanisława Kulczyńskiego w Poznaniu. Podczas kolejnych konkursów młodzi adepci sztuki dyrygenckiej mają możliwość zetknąć się ze znakomicie dobranym repertuarem chóralnym, który później promują w swoich środowiskach.

Nowe utwory chóralne powstawały na zamówienie prężnie rozwijającej się Polskiej Federacji Pueri Cantores. Na I Kongres, który odbył się w Tarnowie w 1997 roku, Marian Sawa skomponował na chór mieszany Cantate Domino in laetitia. Na II Kongres Józef Świder pisze słynne Jubilate Deo na chór mieszany i organy. Henryk Jan Botor komponuje w roku 2007 na Międzynarodowy Kongres Pueri Cantores w Krakowie Misericordias Domini, śpiewane obecnie na całym świecie nie tylko przez 40 tys. chórzystów zrzeszonych w Międzynarodowej Federacji Pueri Cantores, ale także przez inne zespoły chóralne. Na ten kongres powstaje także Missa de misericordias Domini na chór i orkiestrę. Listę 50 utworów zamawianych i opracowywanych dla Federacji Pueri Cantores zamyka Kantata „Ad Fontes" na głosy solowe, chór mieszany i orkiestrę Bartosza Chajdeckiego wykonana podczas viII Krajowego Kongresu Pueri Cantores w Poznaniu w 2015 roku.

Zapotrzebowanie na repertuar dla chórów ciągle jest aktualne. Organizowane w Polsce konkursy kompozytorskie mało uwagi poświęcają chórom jednorodnym, a przecież tych zespołów w szkołach, domach kultury, parafiach mamy najwięcej. Większość utworów pisanych i wydawanych drukiem przeznaczona jest na składy głosów mieszanych.

Obecnie od kilku lat we wszystkich akademiach muzycznych w Polsce organizowane są różnorodne sesje, sympozja, konferencje, festiwale dotyczące chóralistyki zarówno o zasięgu ogólnopolskim, jak i międzynarodowym. Te wszystkie działania organizacyjne i merytoryczne mają ogromny wpływ na profesjonalny rozwój chóralistyki tak bardzo potrzebnej dzisiejszemu człowiekowi.

\section{Bibliografia}

Lasocki J. K., Chór. Poradnik dla dyrygentów, Kraków 1968.

Mazur M. Ł., Vademecum dyrygenta chóru, Otwock 2014.

Puchalski J., Od kultu do radości śpiewania, „Scala. Edukacyjny Magazyn Muzyczny” $2015 \mathrm{nr} 5$ (kwiecień), s. 3-5.

Smagała A., Twórczość kompozytorów polskich w programach Ogólnopolskiego Turnieju Chórów „Legnica Cantat”, praca magisterska niepublikowana.

ks. Stępniak Z., Wybrane polskie chóry akademickie w dwudziestoleciu 1980-20oo. Repertuar - konkursy - wykonania, Lublin 2012. 